\title{
NON-VERBAL MEANING OF KERAWANG GAYO BAJU REJE: MULTIMODAL ANALYSIS
}

\author{
Wulandari Putri Kemas ${ }^{1}$, T. Silvana Sinar ${ }^{2}$, T. Thyrhaya Zein ${ }^{3}$
}

\begin{abstract}
This paper discusses the multimodal analysis of non-verbal meanings in the Kerawang Gayo Reje shirt. It is an ornamental motive made by embroidering cloth. Gayo filigree is the identity of the Gayo. Reje clothes are unique clothes for Reje (king/highest leader) in the village of the Gayonese, and they use several Gayo motives, such as Mata Ni Lao (Matahari), a mandatory motive for a Reje. Each motive contains the meaning of the life of the Gayo tribe. Nowadays, use mandatory clothes on Reje is rarely used. This study aimed to determine the non-verbal meaning of the Kerawang Gayo Reje motives through multimodal analysis. The ethnography method was applied in this study. The data were the Kerawang Gayo Reje shirt's visual art content, the interview result, and observation. The informants were craftsman/tailor; and the Majelis Adat Gayo leaders (Gayo traditional centre) in Central Aceh. The data were analyzed by explaining the meaning lies in the means of communication and each meaning centrally, and dominantly of Kerawang Gayo Reje shirt The result of the study showed that there are four types of motives on Reje's clothes, Mata Ni Lao, Tali Puter Tige, Tekukur, and Tapak Sleman. On the Reje shirt, there is only one colour used, which is yellow. The meaning is justice and prosperity for the Gayo tribe community. It is hoped that a Reje will be fair to the people and provide prosperity for the Gayo tribe community.
\end{abstract}

Keywords: non verbal, kerawang gayo, reje, multimodal

JOMSIGN: Journal of Multicultural Studies in Guidance and Counseling Website: http://ejournal.upi.edu/index.php/JOMSIGN

Permalink: https://ejournal.upi.edu/index.php/JOMSIGN/article/view/31717

How to cite (APA): Kemas, W., P., Sinar, T., S., \& Zein, T.,T. (2021). Non-Verbal Meaning Of Kerawang Gayo Baju Reje: Multimodal Analysis. JOMSIGN: Journal of Multicultural Studies in Guidance and Counseling, 5(1), 31-41.

This is an open-access article distributed under the terms of the Creative Commons Attribution 4.0 International License, which permits unrestricted use, distribution, and reproduction in any medium, provided the original work is properly cited.

\section{INTRODUCTION}

Kerawang Gayo is an ornamental motive that belongs to the Gayo tribe. These motives reflect the system of thought that exists in the life of the Gayo tribe. There are cultural messages and advice in living life that previous elders of the Gayo tribe have given in ornamental motives. Nugraha (2019) stated that the

\footnotetext{
${ }^{1}$ Universitas Sumatera Utara, Indonesia, e-mail: wulandariputrikemas@students.usu.ac.id

${ }^{2}$ Universitas Sumatera Utara, Indonesia, e-mail: tengkusilvana@usu.ac.id,

${ }^{3}$ Universitas Sumatera Utara, Indonesia, e-mail:t.thyrhaya@usu.ac.id
} 
presentation on nature, construct history, development of cultural intelligence and its correlation to the whole human figure leads to an understanding that cultural intelligence is an integrated effort within individuals to function following diverse cultural environments with metacognitive, cognitive, motivational, and behavioral aspects. For the Gayonese, Kerawang Gayo is one of Gayonese creativity and is considered very valuable because it is always used when holding traditional ceremonies to become a symbol and identity for the Gayonese occasions. Susanto (2017) explained that society plays an important role in encouraging the emergence of creativity.

Likewise with Reje (King) clothes. Reje is the highest leader in every village/village in the Gayo tribe community. Reje's position itself is an important part of the Gayo tribe community because Reje will resolve every problem in the village and community life to distinguish a Reje from the community Usually used as a symbol in the form of Kerawang Gayo clothes, which are given some unique motives that are engraved on the clothes, these motives have important meanings, advice, and procedures for good behavior as a leader (Reje) and it is hoped that a Reje can carry out the mandate and responsibility. Following the meaning and mandate contained in each motive contained in the clothes. Nevertheless, nowadays, the use of mandatory motives on Reje's clothes is very rarely found. Reje has used Kerawang Gayo with many combined motives. The Kerawang Gayo found on Reje's clothes is the same as the Gayo Kerawang found in ordinary people. Because people also wear Kerawang Gayo with all existing motives. Even without knowing the meaning contained in the motive.

In connection with the phenomenon of the statement above, several considerations underlie this study. The first reason is that the lack of understanding of the Gayo Tribe Society of the values contained in Kerawang Gayo causes the cultural message contained not to be expressed in everyday life, such as the use of Kerawang Gayo Reje clothes, which are very difficult to find, it is undeniable that the culture that should be defended will be eroded by the times. Because the motives in Kerawang Gayo have many important meanings and messages to be conveyed, as well as the Kerawang Gayo motives found on Reje's clothes, the motives have been determined. They have meaning following the duties of a Reje who carries a great mandate for being a leader. In the Gayo Tribe Society. 
Nevertheless, because the Gayo Tribe Society does not understand the importance of Kerawang Gayo's motives, the message contained in the motives cannot be realized in everyday life. The importance of cultural preservation is the reason for this research. As the Gayo Tribe Society's identity, who never or rarely gets touch from researchers, Kerawang Gayo cannot be denied that it will disappear from the surface of the earth. Along with the community's loss of memory as the Kerawang Gayo motive owner as a cultural identity. Researchers' enthusiasm to maintain and preserve the culture and messages in the Kerawang Gayo motive itself, which is almost extinct, is done by analyzing Kerawang Gayo through a multimodal approach.

Multimodal is a term used to refer to the way people communicate using two or more different modes at the same time (Krese \& Leeuwen, 2001), which can be defined as "The use of several semiotic modes in a product, or semiotic events that occur simultaneously, and by combining these two means to strengthen, complement, or be in a particular arrangement." By using a multimodal approach, it is hoped that not only motives can be interpreted as meaning, philosophy, but the use of openwork fabrics during traditional events can also give a sense of how to use several semiotic modes in products or semiotic events that occur simultaneously, by combining the two means. To complement in analyzing the data. The multimodal approach can convey the relationship between the two in shaping and conveying a text's meaning. This is in line with the view that multimodal includes all interactions, meaning that all communication means to play an important role, both verbal and nonverbal. The language contains meaning, content, or content in the form of information. Information on the symbolic meaning in Kerawang Gayo comes from the arrangement of elements in lines, tones, shapes, and colours.

Ferawati (2013), Kerawang Gayo contains aesthetic values, which include intrinsic value and extrinsic value. In addition to beautifying objects, Kerawang Gayo is also intended for certain symbolic needs. It represents the nature and life of the Gayo Tribe Society, which is contained in each motive's meaning and philosophy. Because it contains a load of values that are solid and deep regarding their aesthetic, symbolic, philosophical, and functional values. Then, Setianingsih et al. (2017) also discuss Kerawang Gayo in understanding Kerawang Gayo's use at wedding ceremonies to find out the symbolic meaning contained in Kerawang Gayo's carvings motives. To find out the role of traditional leaders in developing Kerawang Gayo, it can be said to be a symbol and identity of the Gayo tribe. From the two studies above, the 
results obtained will be very different from this research because Ferawati's research looked at the philosophical values in Kerawang Gayo fabrics. In Fitri's research, researchers looked at the use of Kerawang Gayo fabrics and the motives in fabrics, while in this study, researchers will explain the motives in Reje's clothes and explain their meaning. As well as analyzing these motives using multimodal analysis. So that the motives on Reje's clothes can be interpreted not only verbally but also visually.

\section{METHOD}

In this study, researchers used a qualitative descriptive approach such as transcription of interviews, field notes, pictures, photos, video recordings, etc. This research was conducted in Takengon, Bebesen District, Central Aceh Regency, Aceh Special Region Province. In this study, the data collected were in the form of non-verbal data on Kerawang Gayo, namely in the form of pictures of Reje's clothes and the motives found on Reje's clothes. The informants in this study were determined based on their ability to answer the problem formulation.

The informants in this study were three people consisting: (1) craftsman/tailor; (2) Majelis Gayo Adat (traditional leaders). Data collection was carried out in natural conditions in qualitative research, with data collection techniques on in-depth interviews (in-depth interviews) and documentation. The method used in this research is the ethnography method. An ethnographic record includes field notes, recording devices, pictures, and other objects that document the cultural atmosphere studied by Sugiyono (2013: 225).

\section{FINDINGS AND DISCUSSIONS}

In the Gayo tribe society, the highest power is held by a Reje. In the obligatory Reje clothes, several mandatory motives are specially made and have meanings following the duties of a Reje, namely, Mata Ni Lao Motive, Tali Puter Tige motive, Tekukur motive, Tapak Sleman motive.

When viewed in terms of modality, it is found that the colour of the Kerawang Gayo motive found on Reje's clothes must be made with yellow thread because yellow means justice and prosperity for the Gayo tribe 
community. What is expected by a Reje will be fair to the people and can provide prosperity for the Gayo people.

\section{Modality on Kerawang Gayo clothes Reje}

The motive on the Kerawang Gayo Reje shirt has meaning in terms of colour and shape when viewed in terms of modalities:

\section{Mata Ni Lao motive}

The fullness of detail

Color saturation

Maximum

representation

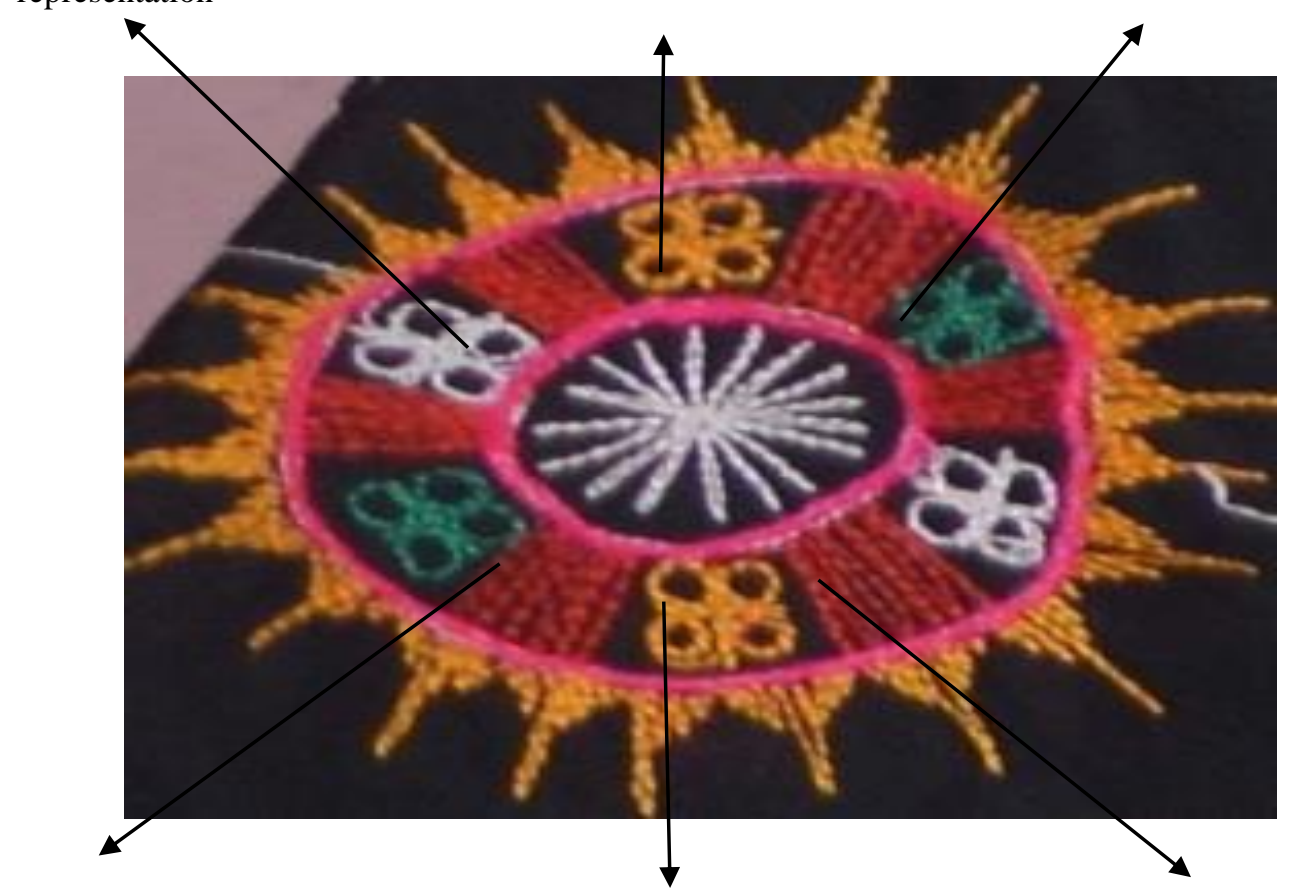

Maximum brightness

Maximum perspective Full representation of light and form

Figure 1. Mata Ni Lao motive

In figure 1, as Sinar (2018) stated, multimodal in the language is a semiotic system that implies that meaning lies in the means of communication. Each means influences meaning centrally and dominantly in the entire communication process in phonics and graphics, namely speech, writing, pictures, and cue. The meaning of the Mata Ni Lao motif symbolizes the source of life for all living things, grateful for the blessings of patience and trials from Allah SWT. The symbol of Mata Ni Lao motif has a cue to describes the relationship between man and the creator and the relationship between fellow beings. The meaning of multimodality in the Mata Ni Lao motif is contextualization, which appears to have detailed motifs that resemble a circle with a triangle around it. The colour saturation in the Mata Ni Lao 
motif is yellow, which means justice and prosperity, and has a black background, which means the soil's primary colour. The maximum representation is depicted as the shape of the sun (Mata Ni Lao). Depth is the maximum perspective that shows the shape of the sun. The illumination is full of light, and the shape is visible from the yellow colour and the shape of the sun-like motif. In the lighting, the maximum brightness is seen.

\section{Motif Tali Puter Tige}

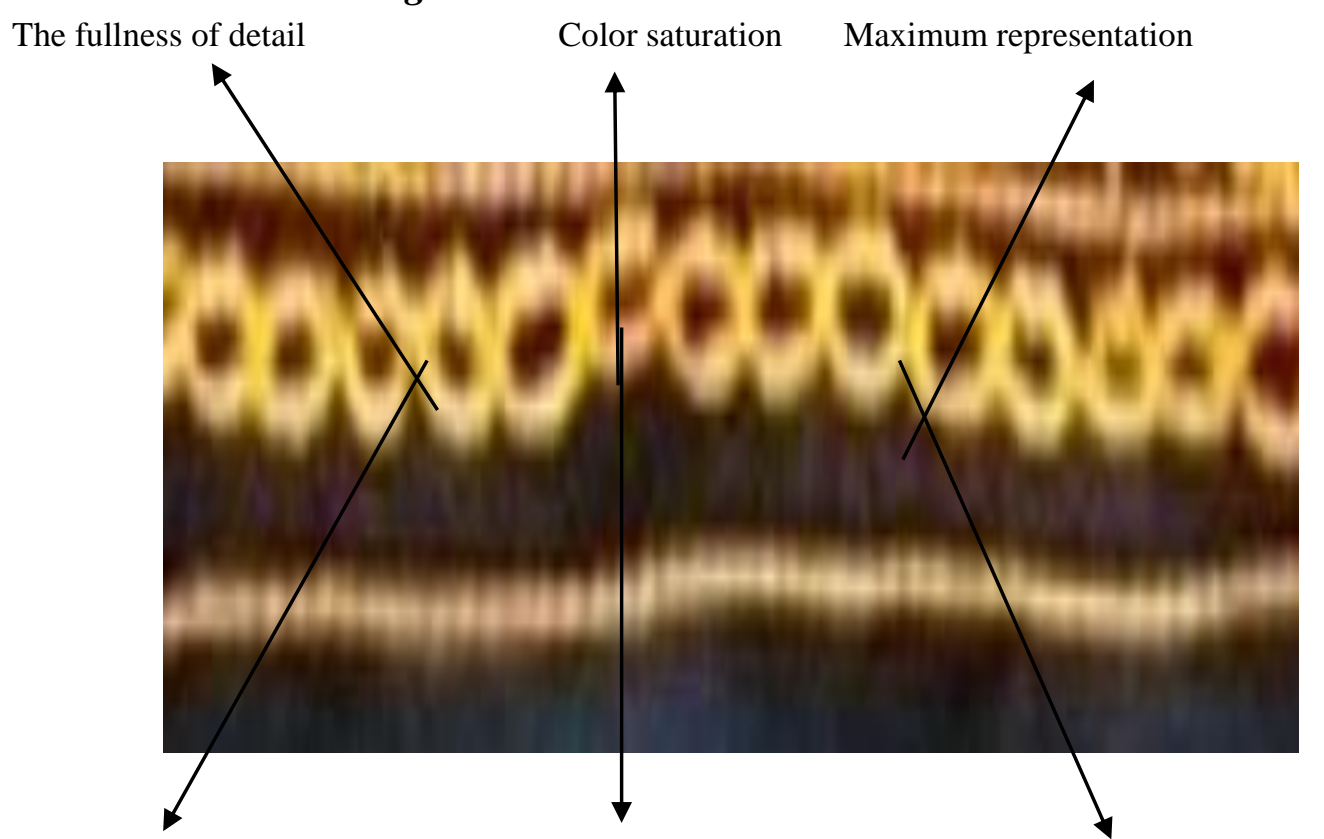

Maximum brightness

Maximum perspective

Full representation of light and form

Figure 2. Tali Puter Tige motive

In figure 2, the meaning of the puter tige cord motive is to be a carrier of goodness and support each other in excellent work. The meaning of multimodality is contained in the contextualized tige white rope motif with detailed motifs that resemble a circle. The colour saturation in the Tali Puter Tige motif is yellow, which means justice and prosperity, and has a black background, which means the primary colour is earth. The maximum representation is depicted very clearly in the form of a circle arranged lengthwise. The depth is the maximum perspective that shows the shape of the rope that is swirling together. The illumination looks full of light, and the shape is visible from the yellow colour and the shape of the motif that is like a spinning rope. In the lighting, the maximum brightness is seen. 


\section{Tekukur motive}

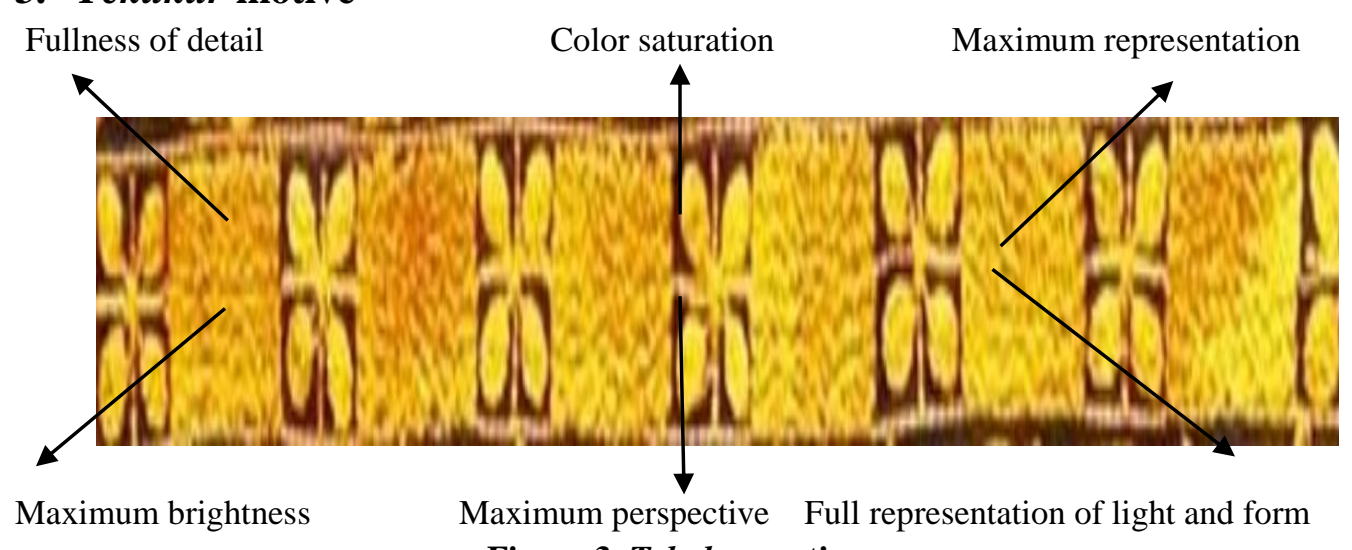

Figure 3. Tekukur motive

The meaning contained in figure 3, the Tekukur motive, is to be wise and full of consideration in making decisions. The multimodality meaning contained in the Tekukur motif is the contextualized Tekukur motif, which appears to have detailed motifs that resemble the shape of four circles that are bordered like a plus sign in the middle. The colour saturation in the Tekukur motif is yellow, which means justice and prosperity, and has a background that means the primary colour, namely soil. The maximum representation is drawn very clearly in the form of four circles. The depth is the maximum perspective showing the shape of four circles bordered like a plus sign in the middle. The illumination looks full of light, and the shape is visible from the yellow colour and the shape of the motif. In the lighting, the maximum brightness is seen.

\section{Tapak Sleman motive}

Fullness of detail

Color saturation

Maximum representation

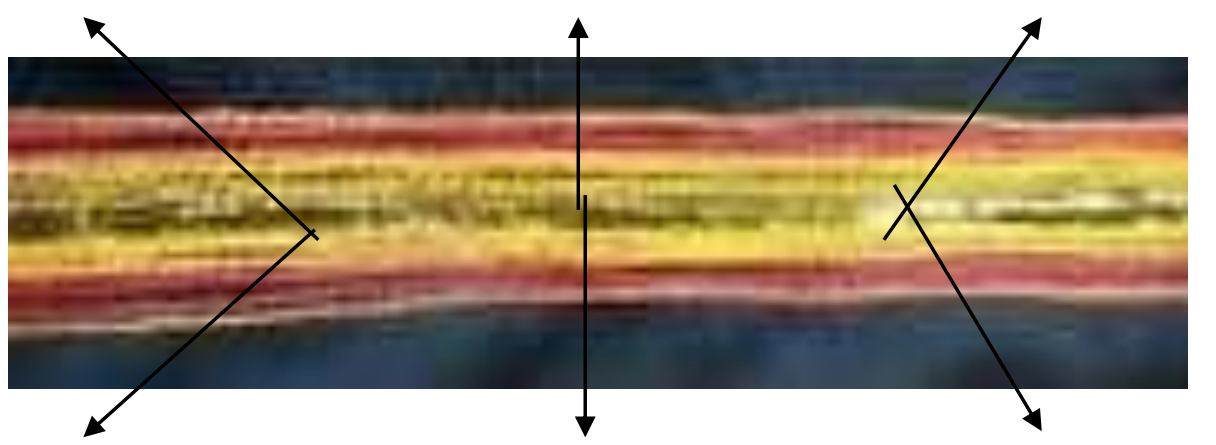

Maximum brightness

Maximum perspective Full representation of light and form Figure 4. Tapak Sleman motive

Ferawati (2013) explained the motifs in the wedding dress. The researcher would uncover Kerawang Gayo's meaning in the verbal text and 
visual text using the LSF-based multimodal theory, which will explain the concept of language metafunctions, namely experimental functions, interpersonal functions, and textual functions. Rahmah (2015) describes the dynamics of the traditional marriage celebrations of the Medan Malay community. This research applies multimodal analysis to cultural discourse to find the meaning created by the verbal and visual components that refer to social semiotic analysis.

In figure 4, the meaning contained in the Tapak Sleman motif is that all problems must be handled thoroughly, wisely, and wisely. The multimodal meaning contained in the Tapak Sleman motif is contextualized, which appears to have detailed motifs that resemble straight lines. The colour saturation in the Tapak Sleman motif is yellow, which means justice and prosperity, and has a black background, which means the primary colour is soil. The maximum representation is drawn very clearly in the form of a long straight line. Depth is a maximum perspective that shows a straight line. The illumination looks full of light and forms visible from the yellow and red. In the lighting, the maximum brightness is seen.

Salihin (2019), Kerawang Gayo's motive has several sources of ideas in its creation that depart from ancient events and society's environment. The values contained in each motive have philosophical values and become a guide in the life of the Gayo tribe. Each text is a variety of genres with a schematic structure of each genre and can be different or vary in each genre. Story genres such as narrative, tale, myth, anecdote, fable, romance, horror, hero, moral story, fairy tales have an abstract schematic structure (n)^ orientation $(\mathrm{n})^{\wedge}$ complications $(\mathrm{n})^{\wedge}$ resolution $(\mathrm{n}) \wedge($ evaluation $)(\mathrm{n})^{\wedge}($ koda $)$ and factual genres such as exposition, the discussion has a schematic structure of the position of the University of North Sumatra 20 (elements that state the position), thesis (elements of factual statements support the position), argumentation (elements of evaluation of statements, opinions, and assessment) and conclusions/suggestions (the closing element in the exposition text states the assessment, invitation, and suggestion of the author) and thus other structures in the genre (Sinar, 2014).

When viewed from a multimodal perspective, especially language that can be interpreted through symbols or pictures, several things can be discussed. From the Kerawang Gayo carvings' language aspect, there is still powerful language and culture in each motif. Kerawang Gayo is still a pride 
for the Gayo people themselves. Both the old and the young often use Kerawang Gayo as something that can show the characteristics of their tribe, and local governments also use Kerawang Gayo motifs on office clothes and school children's clothes. They must be used to remind us of the existing culture. However, the understanding of the Gayo community itself about the forms of motives and their meanings is still very minimal, even though the Gayo tribe elders in ancient times kept many messages and mandates for their descendants, conveyed through the symbol on the motive. Likewise, with the mandatory motives on Reje's clothes, their use has been regulated according to the mandate that they have to carry.

Sinar (2018), multimodal in the language, is a semiotic system that implies that meaning lies in the means of communication. Each means influences meaning centrally and dominantly in the entire communication process in phonics and graphics, namely speech, writing, pictures, and cue. Tantawi \& Buniyamin (2011) Kerawang Gayo Lues has the motives of Mata Itik, Pucuk Rebung, Sesirung, Leladu, Mun Berangkat, Tulenni Iken, Puter tali, Bunge Kipes, Gegaping, Bunga Panah, Motif Selalu. Whereas the Kerawang Central Aceh motives consists of Tapak Sleman, Mata Ni Lo, Cucuk Pengong, Tali Puter Tige, Pucuk Ni Tuis, Emun Mupesir, Emun Berangkat, Emun Beriring, Emun Berkune, Puter Tali, Tekukur, Tali Mustike, sarak Opat dan Peger.

For this reason, it is feared that the next generation will not know the types of motives and their meanings. Thus, research using this multimodal analysis can increase the Gayo tribe community's knowledge about the meaning, motive, and importance of Kerawang Gayo. Ningsih et al. (2018), each Kerawang Gayo motive is a traditional symbol in tanoh Gayo, while the Kerawang Gayo motive found in Upuh Ulen-ulen Central Aceh consists of ten motives, while the Kerawang motive in Upuh Kerawang Gayo Lues consists of eleven motifs with the difference between the two totaling seven motives.

Actually for other positions in the Gayo tribe community, such as Imem and Petua, also have mandatory motives on their clothes, all of which are following the positions and responsibilities they carry so that it is hoped that there will be other research that can be continued to increase knowledge and so that the culture contained in the Gayo tribe does not become extinct.

\section{CONCLUSION AND RECOMMENDATION}


The modalities contained in Reje's clothes consist of the fullness of details, colour saturation, maximum representation, maximum perspective, maximum illumination, and full representation of light and form. On Reje's clothes, all motifs must be made with yellow thread, which means justice and prosperity. On Reje's clothes, the application of motifs is not made carelessly because the motifs on Reje's clothes have meaning, advice, and hope that a Reje behaves following the Gayo's expectations tribe. On the Reje shirt, the basic cloth is black, and the motifs required on Reje clothes are Mata Ni Lao, Tali Puter Tige, Tekukur, and Tapak Sleman. This finding will be used as the reference for further relevant research such as Kerawang Gayo's values, the character, and other disciplines related to Gayonese cultural and non-verbal meaning.

\section{ACKNOWLEDGEMENTS}

The author would like to thank all parties who have played a role in helping this research.

\section{REFERENCES}

Ferawati. (2013). Motif Kerawang Gayo pada Busana Adat Pengantin di Aceh Tengah. Ekspresi Seni : Jurnal Ilmu Pengetahuan Dan Karya Seni, 15(1), 29-39.

Krese, G., \& Leeuwen, T. V. (2001). Handbook of Visual Analysis. SAGE Publications.

Ningsih, J., Selian, R. S., \& Palawi, A. (2018). Perbedaan Motif Kerawang Gayo Lues dan Aceh Tengah. Jurnal Ilmiah Mahasiswa Program Studi Pendidikan Seni Drama, Tari Dan Musik, 3(4), 356-367.

Nugraha, A. (2019). Cultural Intelligence in the Diversity of Science. JOMSIGN: Journal of Multicultural Studies in Guidance and Counseling, 3(2), 90-105.

Rahmah. (2015). Multimodal Dinamika Perayaan Perkawinan Adat Masyarakat Melayu Medan. Universitas Sumatera Utara.

Salihin, A. (2019). Analisis Motif Pucuk Rebung Kerawang Gayo. Jurusan Seni Kriya, Fakultas Seni Rupa dan Desain, Institut Seni Indonesia.

Setianingsih, P., Dafrina, A., \& Lisa, N. P. (2017). Analisis Semiotika Simbol pada Umah Pitu Ruang di Kabupaten Aceh Tengah. Prosiding Temu Ilmiah IPLBI 2017, 39-46. 
Non-Verbal Meaning of Kerawang Gayo Baju Reje: Multimodal Analysis

Sinar, T. S. (2014). Teori dan Analisis Wacana: Pendekatan Linguistik Sistemik Fungsional. Mitra.

Sinar, T. S. (2018). Analisis Wacana Multimodal. Teori Linguistik Sistemik Fungsional. USU Press.

Sugiyono. (2013). Metode Penelitian Kuantitatif Kualitatif dan $R \& D$. Alfabeta.

Susanto, E. (2017). Budaya Kreatif dalam Konsep dan Pengembangan. JOMSIGN: Journal of Multicultural Studies in Guidance and Counseling, 1(2), 191-200.

Tantawi, I., \& Buniyamin. (2011). Pilar-Pilar Kebudayaan Gayo Lues. USU Press. 